\title{
EFEKTIVITAS PENGGUNAAN INTERVENSI FISIOTERAPI TERAPI LATIHAN DAN INFRARED PADA KASUS DISLOKASI SENDI BAHU
}

\author{
Aflah Tasya Salim ${ }^{1)}$; Andrew Wijaya Saputra ${ }^{2)}$ \\ 1) aflahtasya2002@gmail.com, Politeknik Kesehatan Hermina \\ 2)andrew.wijaya@poltekkeshermina.ac.id, Politeknik Kesehatan Hermina
}

\begin{abstract}
Basic activities are in the form of a necessity and human need, especially in the era of globalization as it is now. Upper limbs have a very high involvement in all activities carried out by humans. Everything that is done daily, especially activities on the function of the upper limbs. Hands and arms are the main actors, so that if certain disturbances occur, it will interfere with mobility and human activities. The shoulder joint is one of the most commonly dislocated large joints, this can occur due to the wide range of motion of the joint, the shallowness of the glenoid fossa, and ligament laxity in some people. Dislocation of the shoulder joint is a condition in which the humeral head shifts from the glenohumeral joint, so that it can cause nerve damage and can occur repeatedly. This journal aims to explain the effectiveness of providing exercise therapy and infrared therapy in shoulder dislocation cases and the reader's knowledge about shoulder dislocation cases. The research method used is descriptive qualitative by taking material based on a literature review. The results showed that providing exercise therapy and infrared therapy to reduce pain, increase muscle strength, increase range of motion, and improve the ability of patients suffering from joint dislocation cases.
\end{abstract}

Keywords : Trauma, Shoulder joint dislocation, Exercise therapy, Infrared

\begin{abstract}
Abstrak
Kegiatan dasar berupa gerak merupakan suatu kebutuhan dan tuntutan manusia terutama dalam era globalisasi seperti sekarang. Anggota gerak atas memiliki keterlibatan yang sangat tinggi dalam semua aktivitas yang dilakukan oleh manusia. Seluruh aktivitas yang dilakukan sehari-hari banyak bergantung terutama pada fungsi anggota gerak atas. Tangan dan lengan merupakan pemeran utama, sehingga apabila terjadi gangguan tertentu, hal tersebut akan mengganggu mobilitas dan kegiatan manusia. Sendi bahu merupakan salah satu sendi besar yang paling umum terjadi dislokasi, hal tersebut dapat terjadi karena rentang gerak sendi yang luas, dangkalnya fossa glenoid, dan ligament laxity pada beberapa orang. Dislokasi sendi bahu merupakan suatu kondisi dimana terjadi pergeseran caput humerus dari sendi glenohumeral, sehingga hal tersebut dapat menyebabkan kerusakan pada saraf serta dapat terjadi berulang. Jurnal ini bertujuan untuk menjelaskan efektivitas pemberian intervensi terapi latihan dan terapi infrared pada kasus dislokasi sendi bahu dan menambah pengetahuan pembaca mengenai kasus dislokasi sendi bahu. Metode penelitian yang digunakan yaitu deskriptif kualitatif dengan pengambilan materi berbasis literature review. Hasil penelitian menunjukkan bahwa pemberian terapi latihan dan terapi infrared efektif untuk menurunkan nyeri, meningkatkan kekuatan otot, meningkatkan lingkup gerak sendi (LGS), serta meningkatkan kemampuan fungsional pasien yang menderita kasus dislokasi sendi.
\end{abstract}

Kata Kunci : Trauma, Dislokasi sendi bahu, Terapi Latihan, Infrared

\section{PENDAHULUAN}

Perilaku manusia yang selalu menginginkan sesuatu serba cepat, praktis dan ekonomis tanpa memperdulikan keselamatannya meningkatkan risiko tekena penyakit yang disebabkan oleh trauma. Trauma merupakan penyebab kematian ketiga pada semua kelompok umur setelah penyakit kardiovaskular dan kanker (Dogrul, 2020). Menurut (Celcilia, 2015) jumlah kematian yang disebabkan oleh trauma diproyeksikan meningkat 3,3 juta jiwa dari sekitar 5,1 juta menjadi 8,4 juta, dengan total kematian 9,2 juta jiwa dan diperkirakan menempati peringkat ketiga disability adjusted life years (dalys) pada tahun 2020.

Trauma adalah suatu kondisi di mana seseorang mengalami cidera parah akibat benturan atau pukulan benda tumpul (DocDoc Pte Ltd, 2020). Hal tersebut dapat menimbulkan rasa sakit, panas, kemerahan, bengkak, dan tidak berfungsinya otot, tendon, ligamen, sendi, dan tulang akibat aktivitas fisik yang berlebihan atau karena suatu kecelakaan (Priyonoadi, 2012). Kecelakaan yang dialami seseorang dapat menyebabkan cedera ringan ataupun serius. Kecelakaan juga dapat menyebabkan kecacatan ataupun kematian. Cedera ringan dapat berupa 
sprain atau strain, sedangkan cedera serius dapat berupa fraktur hingga dislokasi, misalnya dislokasi pada bahu (Ozan, 2019).

Pada umumnya cedera dislokasi bahu disebabkan karena jatuh mendadak dengan posisi menumpu pada bahu di permukaan keras, terkena pukulan atau tendangan di lengan bagian atas dan lain sebagainya, sehingga mengakibatkan caput humerus keluar atau bergeser dari soket bahu. Hal ini sesuai dengan penelitian yang dilakukan oleh (Legiran, 2015) yang menyatakan bahwa sebanyak 50 dari 64 kasus dislokasi atau sekitar 90,9\% disebabkan oleh trauma, sedangkan untuk kasus dislokasi yang disebabkan oleh kondisi patologik hanya terdapat 5 kasus atau sebesar $9,1 \%$ dengan 4 kasus $(7,3 \%)$ akibat penyakit degeneratif osteoarthritis dan 1 kasus $(1,8 \%)$ akibat rheumatoid arthritis.

Pada kasus dislokasi bahu yang parah, dapat merusak jaringan dan saraf di sekitar sendi bahu. Akibat dari cedera ini, seseorang akan merasakan nyeri parah pada bahu dan lengan atas yang mengakibatkan lengan sulit untuk digerakkan. Dapat juga terjadi deformasi bahu yang terlihat sebagai tonjolan di bagian depan atau belakang bahu. Apabila sendi sudah pernah mengalami dislokasi, maka biasanya ligamen-ligamen pada sendi tersebut sudah menjadi longgar sehingga meningkatkan resiko terjadinya dislokasi kembali (Setiyawan, 2013). Hal ini sesuai dengan penelitian yang dilakukan oleh (Legiran, 2015) yang menemukan bahwa sebanyak 13 dari 55 kasus dislokasi atau sekitar 23,6\% terjadi secara kronik atau terjadi dislokasi berulang. Sehingga semakin awal usaha pengembalian sendi itu dilakukan, maka semakin baik pula proses penyembuhannya. Untuk mengambalikan kondisi bahu ke keadaan normal, orang-orang yang mengalami dislokasi bahu biasanya melanjutkan pengobatannya dengan mengikuti fisioterapi (Nugraha, 2020). Berdasarkan uraian di atas tujuan dari penelitian ini adalah untuk mengetahui manfaat dan efektivitas penggunaan intervensi terapi latihan dan infrared terhadap penurunan nyeri, peningkatan kekuatan otot dan peningkatan lingkup gerak sendi pada kasus dislokasi bahu.

\section{METODE}

Metode penelitian yang digunakan yaitu deskriptif kualitatif dengan pengambilan materi berbasis literature review. Tinjauan pustaka dari penelitian sebelumnya berperan dalam membentuk kerangka kerja untuk penelitian ini. Pengumpulan data dilakukan dengan mendokumentasi dan mereview semua artikel terkait dislokasi sendi dalam kurun waktu 2013 - 2021. Artikel yang digunakan pada penelitian ini diperoleh dari dua database yaitu Google Scholar dan PubMed.

Secara umum, literature review didefinisikan sebagai ringkasan yang diperoleh dari sumber bacaan yang relevan dengan pembahasan penelitian. Latar belakang mencakup fungsi persiapan pengumpulan data faktual yang umumnya akan dimasukkan dalam tinjauan pustaka dalam setiap survei dan studi empiris. Melalui pandangan baru pada penelitian terbaru, tinjauan pustaka ini juga digunakan untuk menciptakan sebuah konteks masa lalu (Ridwan, 2021). Literature review meliputi ulasan penulis, ringkasan, dan pemikiran dari berbagai sumber di perpustakaan (bisa berupa Jurnal, informasi dari internet, slide. Buku, dan sebagainya) mengenai topik yang dibahas oleh peneliti selanjutnya dan biasanya terdapat pada bab awal (syafnidawaty, 2020). Menurut Sarwono dalam (Ridwan, 2021) Tujuan utama dari tinjauan pustaka adalah untuk mendapatkan pemahaman yang lebih dalam tentang variabel penelitian, mengklasifikasikan hal yang dibutuhkan dan yang tidak dibutuhkan, menghindari plagiarism artikel, mensintesis dan menyerap perspektif baru, dan menemukan korelasi hubungan antar variable. 
Tabel 1. Penggunaan Literature Review

\begin{tabular}{|c|c|c|}
\hline $\begin{array}{l}\text { No } \\
1\end{array}$ & Deskripsi Jurnal & Pembahasan \\
\hline \multirow[t]{10}{*}{1} & Judul Penelitian : & Hasil Penelitian : \\
\hline & Penatalaksanaan Fisioterapi & 6 kali terapi menggunakan \\
\hline & Pada Post Dislokasi Shoulder & intervensi infrared dan terapi latihan di dapatkan hasil \\
\hline & Dextra & $\begin{array}{l}\text { penurunan nyeri gerak dari } \mathrm{T} 15 \text { menjadi } 3 \text {, } \\
\text { meningkatnya kekuatan otot fleksor ekstensor }\end{array}$ \\
\hline & Tahun : & abduktor, adduktor, endorotasi dan eksorotasi dari 3 \\
\hline & 2013 & $\begin{array}{l}\text { menjadi } 5 \text {, meningkatnya LGS sendi shoulder, } \\
\text { peningkatan aktifitas fungsional pada terapi ke- } 6 \text {. }\end{array}$ \\
\hline & Peneliti : & Sehingga dapat ditarik kesimpulan bahwa infrared \\
\hline & Arief Setiyawan & $\begin{array}{l}\text { dan terapi latihan dapat mengurangi nyeri, } \\
\text { meningkatkan kekuatan otot. meningkatkan lingkup }\end{array}$ \\
\hline & Metode Penelitian : & gerak sendi bahu dan meningkatkan kemampuan \\
\hline & Pengujian sample data pasien & fungsional. \\
\hline
\end{tabular}

Nama Jurnal :

Karya Tulis Ilmiah (Tugas Akhir)

\section{Alasan Menjadi Tinjauan Penelitian :}

Jurnal berikut memperkuat penelitian ini dengan memberikan pembahasan mengenai hasil pemberian terapi menggunakan intervensi infrared dan terapi latihan dalam menangani pasien dengan kasus dislokasi bahu.

\section{Perbedaan Dengan Penelitian Yang Akan \\ Dilakukan :}

Penelitian dalam jurnal ini menggunakan data sample satu orang pasien, sedangkan pada penelitian yang akan dilakukan hanya mereview dan meringkas berdasarkan hasil penelitian yang dilakukan oleh peneliti sebelumnya serta menambahkan teori berdasarkan penelitian sumber lain.

\section{Judul Penelitian :}

Penatalaksanaan Fisioterapi Dengan Terapi Latihan Dan Infra Red (IR) Pada Kondisi Post Dislokasi Sendi Acromioclavicular Dextra

Tahun :

2013

Peneliti :

Heru Bahari Samudro

\section{Hasil Penelitian :}

Pelaksanaan terapi menggunakan infared dan terapi latihan menunjukan pekembangan yang positif, yaitu adanya penurunan nyeri pada bahu kanan. Skala nyeri tekan berkurang dari 4 menjadi 3, dan skala nyeri gerak berkurang dari 3 menjadi 2. Serta terdapat peningkatan ROM dan kekuatan otot. Dari hasil data yang diperoleh selama terapi diperoleh kesimpulan bahwa penggunaan modalitas fisioterapi yang telah diterapkan di atas dapat membantu mengatasi masalah dislokasi acromionclavicula joint dextra.

\section{Alasan Menjadi Tinjauan Penelitian :}

Metode Penelitian :

Pengujian sample data pasien

Nama Jurnal :

Jurnal berikut memperkuat penelitian ini dengan memberikan pembahasan mengenai hasil pemberian terapi menggunakan intervensi infrared dan terapi latihan dalam menangani pasien dengan kasus dislokasi bahu.

Karya Tulis Ilmiah (Tugas

Akhir) 


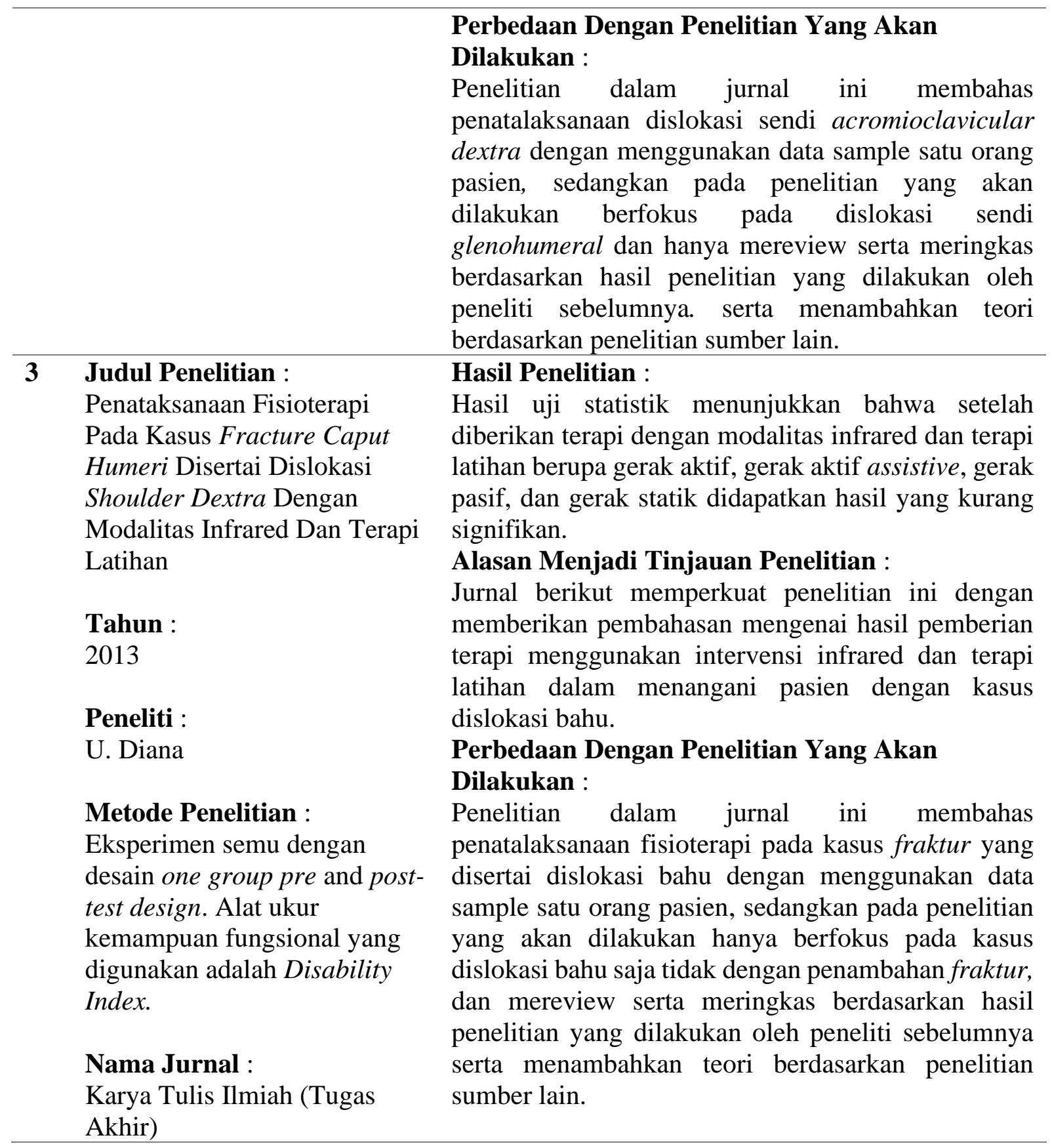

\section{HASIL DAN PEMBAHASAN \\ Anatomi Dan Fisiologi Sendi Bahu}

Sendi bahu merupakan persendian yang paling kompleks pada struktur tubuh manusia, yang bertanggung jawab untuk menghubungkan ekstremitas atas dengan batang tubuh. Sendi bahu terbentuk oleh empat tulang yaitu scapula, clavicula, humerus, dan sternum. Persendian pada bahu terdiri atas empat sendi, yaitu sendi sternoclavicular yang terletak paling proximal terbentuk oleh tulang sternum dan clavicula, berfungsi sebagai penyangga mekanis, atau penopang yang memegang scapula pada jarak yang relatif konstan dari batang tubuh. Sendi yang terletak di ujung lateral clavicula adalah sendi acromioclavicular, ligament yang terletak pada sendi ini menempelkan acromion ke clavicula. Permukaan anterior dari scapula bersandar pada permukaan posterior-lateral toraks, sehingga membentuk sendi scapulothoracic, artikulasi tersebut bukan merupakan true joint secara anatomis, melainkan hanya antarpermukaan tulang. 
Gerakan pada sendi scapulothoracic secara mekanis terkait dengan gerakan di kedua sendi yaitu sendi sternoclavicular dan sendi acromionclavicular. Posisi scapula pada toraks memberikan dasar untuk sendi glenohumeral, yaitu sendi yang paling distal dan mobile pada persendian shoulder complex. Istilah "gerakan bahu" menggambarkan gerakan gabungan pada sendi glenohumeral dan sendi scapulothoracic (Neumann, 2017).

Empat sendi tersebut bekerjasama secara sinkron untuk menggerakkan lengan. Aktivitas menusia yang banyak bergantung pada fungsi ekstremitas atas terutama pada bahu menimbulkan berbagai masalah patologis dan muskuloskeletal yang terjadi. Oleh karena itu, pemahaman mengenai anatomi sendi ini diperlukan untuk memahami keadaan normal, dan patologis pada bahu, serta untuk membantu dalam penegakkan diagnosis (Bakhsh, 2018). Sendi bahu adalah sendi yang paling umum terjadi dislokasi, dikarenakan rentang gerak pada sendi glenohumeral yang luas, dangkalnya fossa glenoid, dan juga ligament laxity pada beberapa orang (Samudro, 2013). Cedera jenis ini sering dialami oleh orang-orang yang banyak bekerja dengan menggunakan lengannya secara aktif sepeti seorang olahragawan. Hal ini sesuai dengan penelitian yang dilakukan oleh Apey dalam (Legiran, 2015) yang menyatakan bahwa sekitar 48,3\% kasus terjadi akibat trauma seperti pada kegiatan olahraga.

Menurut (Adams, 1972, pp. 235-236) terdapat beberapa tipe dislokasi berdasarkan pada penyebab terjadinya, yang dapat diklasifikasikan sebagai berikut:

1. Dislokasi congenital yaitu dislokasi yang terjadi sejak lahir akibat kesalahan pertumbuhan.

2. Dislokasi patologik yaitu dislokasi yang terjadi akibat dari penyakit sendi dan atau jaringan sekitar sendi. misalnya tumor, infeksi, atau osteoporosis tulang. Hal ini disebabkan karena berkurangnya kekuatan tulang

3. Dislokasi traumatik yaitu dislokasi yang terjadi sehingga menyebabkan kondisi darurat ortopedi seperti kehilangan pasokan darah, kerusakan sistem saraf dan stress berat, dan kematian jaringan karena kekurangan oksigen. Hal ini terjadi sebagai akibat dari trauma yang signifikan yang dapat menyebabkan tulang bergeser dari jaringan sekitarnya dan juga dapat merusak struktur sendi, ligamen, saraf, dan sistem vascular. Dislokasi traumatik biasanya terjadi pada orang-orang dewasa, karena tingginya tangkat aktivitas fisik berat yang dilakukan dapat meningkatkan risiko terjadinya dislokasi.

4. Dislokasi berulang yaitu dislokasi yang terjadi akibat longgarnya ligament-ligament pada suatu sendi karena pernah mengalami dislokasi.

\section{Etiologi}

Dislokasi biasanya terjadi akibat benturan yang tiba-tiba yaitu yang disebabkan kerena seseorang terjatuh, terpukul benda keras, atau cedera lainnya. Ketika seseorang terjatuh tulang humerus akan terdorong ke depan, sehingga merobek kapsul atau menyebabkan tepi glenoid teravulasi, dan terkadang menyebabkan pecahnya bagian posterolateral caput humerus (Setiyawan, 2013). Pada kasus post dislokasi acromionclavicula joint dextra terjadi karena trauma yang datang dari arah anterior atau jatuh dengan posisi lengan dalam keadaan hiperfleksi akibat tekanan dalam usaha untuk mempertahankan tubuh atau karena overuse (penggunaan gerakan yang berlebihan) dari sendi glenohumeral (Samudro, 2013).

Dalam 90\% kasus, dislokasi bahu anterior mempengaruhi individu muda, banyak di antaranya adalah atlet. Mekanismenya bisa langsung atau tidak langsung dengan dorongan maju dari lengan yang ditinggikan dan diputar ke luar (misalnya, selama smash bola basket) atau jatuh di telapak tangan dengan lengan terentang (F, 2015). 


\section{Indonesian Journal of Health Science}

Volume 1 No. 1, Juni 2021

\section{Insiden dan Prevalensi}

Dalam sebuah studi di Amerika Serikat dilaporkan bahwa kasus dislokasi sendi bahu berupa $95 \%$ dislokasi anterior, $4 \%$ dislokasi posterior, $0,5 \%$ dislokasi inferior, serta kurang dari 0,5\% dislokasi superior (Koval, 2006). Dislokasi sendi bahu sering terjadi pada orang dewasa, jarang terjadi pada anak-anak (Apley, 2010) di mana dari 71,8\% pria yang mengalami dislokasi, 46,8\% pasien berusia15-29 tahun, dan 48,3\% disebabkan karena trauma seperti aktivitas olahraga. Tingkat dislokasi yang lebih tinggi telah diamati pada wanita di atas usia 60 tahun. Penyebab terbanyak ditemukan dengan angka 58,8\% adalah jatuh. Pada beberapa kasus atau sekitar $16 \%$ kasus dislokasi bahu juga disertai dengan fraktur penyerta pada komponen sendi (Zachilli, 2010).

Pada penelitian yang dilakukan oleh (Legiran, 2015) terhadap 64 kasus dislokasi sendi bahu di Subbagian Bedah Ortopedi RSUP Dr. Mohammad Hoesin Palembang pada periode Januari 2012 - Desember 2013, dengan hanya 55 subjek yang memenuhi kriteria inklusi dan eksklusi. Dislokasi sendi bahu paling sering terjadi pada usia 14-24 tahun yaitu sebanyak 16 kasus $(29,1 \%)$. Kasus paling sedikit ditemui pada usia 58-68 tahun yaitu hanya 1 kasus $(1,8 \%)$ dan usia 69-79 tahun sebanyak 3 kasus (5,5\%) (Kasyfi, 2020).

\section{Table 2. Prevalensi Berdasarkan Usia}

\begin{tabular}{lll}
\hline \multicolumn{1}{c}{ Usia } & $\mathbf{N}(\mathbf{5 5})$ & \multicolumn{1}{c}{$\%$} \\
\hline 3-13 tahun & 6 & 10,9 \\
$\mathbf{1 4 - 2 4}$ tahun & 16 & 29,1 \\
$\mathbf{2 5 - 3 5}$ tahun & 10 & 18,2 \\
$\mathbf{3 6 - 4 6}$ tahun & 9 & 16,4 \\
$\mathbf{4 7 - 5 7}$ tahun & 10 & 18,2 \\
$\mathbf{5 8 - 6 8}$ tahun & 1 & 1,8 \\
69-79 tahun & 3 & 5,5 \\
\hline Total & $\mathbf{5 5}$ & $\mathbf{1 0 0}$ \\
\hline
\end{tabular}

\section{Manifestasi Klinis}

Pada dislokasi bahu anterior umumnya dikarenakan jatuh dalam keadaan out stretched, trauma pada scapula dengan gambaran klinis pada dislokasi jenis ini adalah nyeri hebat dan gangguan pergerakan bahu, permukaan sendi bahu jadi rata, dan caput humerus bergeser ke arah anterior. Pada pemeriksaan radiologis ditemukan adanya deformitas dengan caput humerus berada di anterior dan medial glenoid cavity. Pada dislokasi bahu posterior terlihat trauma langsung pada sendi bahu dalam keadaan internal rotasi, dengan gejala nyeri dan terdapat benjolan di bagian posterior sendi saat dilakukan pemeriksaan radiologis. Pada dislokasi inferior dapat dilihat bahwa caput humerus terjepit di bawah glenoid cavity, dengan lengan mengarah ke atas.

Bergesernya acromioclavicula dari persendian dan gleoidal cavity akan mengakibatkan hilangnya kontinuitas sinaptik yang normal, yang mengakibatkan ruptur atau cedera otot-otot rotator cuff. Kerusakan jaringan ini menyebabkan pembuluh darah rusak sehingga menimbulkan pembengkakan (edema). Post dislokasi sendi acromionclavicular ditandai adanya sesuatu yang menonjol ke depan sehingga menimbulkan masalah, salah satunya yaitu terdapat nyeri tekan dan nyeri gerak, akibat kerusakan jaringan di sekitar sendi dan letak sendi, 


\section{Indonesian Journal of Health Science}

Volume 1 No. 1, Juni 2021

serta lengan yang menempek pada batang tubuh dengan posisi lengan bawah external rotasi (Samudro, 2013).

\section{Proses Penyembuhan Dislokasi}

\section{Inflamasi}

Inflamasi merupakan tahap pertama proses penyembuhan dislokasi. Fase ini dimulai sejak terjadinya kerusakan dan berlangsung selama 3-7 hari. Fase inflamasi secara klinis ditandai dengan cardinal sign; kemerahan yang terjadi karena pelebaran kapiler darah (rubor), suhu hangat (kalor), rasa nyeri (dolor), dan pembengkakan (tumor), serta fungction laesa. Saat seseorang sudah mengetahui tanda-tanda bahwa ia terkena dislokasi, segeralah merujuk ke rumah sakit untuk dilakukan tindakan reposisi atau mengembalikan tulang yang bergeser ke tempat yang seharusnya.

2. Proliferasi

Tahap penyembuhan dislokasi yang dimulai seminggu setelah terjadinya kerusakan dan berakhir paling lambat 1 bulan. Proliferasi ditandai dengan monculnya fibroblast. Setelah terjadinya kerusakan, fibroblast kemudian akan bergerak ke jaringan di sekitar luka atau cidera dan masuk ke dalam daerah kerusakan, kemudian berkembang dan mengeluarkan beberapa substansi seperti kolagen, elastin, asam hyaluronic, fibronectin dan profeoglycans yang berperan dalam rekonstruksi jaringan baru.

3. Remodeling

Selama fase ini terjadi proses pematangan yang terdiri atas reabsorbsi jaringan berlebih, yang dimulai pada minggu ke-3 dan berakhir hingga 12 bulan. Tujuan dari fase ini adalah untuk menyelesaikan pembentukan jaringan baru menjadi jaringan penyembuhan yang kuat.

\section{Pemeriksaan dan Pengururan yang Berkaitan dengan Dislokasi}

Pemeriksaan pada kondisi dislokasi sendi bahu meliputi:

1. Anamnesis

Anamnesis adalah pemeriksaan yang dilakukan dengan tanya jawab kepada pasien mengenai keadaan umum dari pasien. Interview tersebut meliputi: data diri pasien, keluhan utama, riwayat penyakit sekarang, riwayat penyakit dahulu, riwayat penyakit penyerta, dan riwayat penyakit keluarga.

2. Pemeriksaan Fisik

a. Vital sign

b. Inspeksi (melihat keadaan sendi bahu apakah ada tanda-tanda inflamasi)

c. Palpasi (mempalpasi sendi bahu untuk melihat apakah ada bengkak)

d. Perkusi

e. Auskultasi (untuk mendengarkan apakah ada krepitasi sendi)

f. Pemeriksaan Gerak yaitu dengan memeriksa gerak pasif, aktif, dan gerak isometrik melawan tahanan

g. Pemeriksaaan kognitif, intra personal dan interpersonal pasien

h. Kemampuan ADL pasien yang meliputi kemampuan fungsional dasar, aktivitas fungsional, dan lingkungan aktivitas.

3. Pemeriksaan Spesifik

a. Pemeriksaan nyeri dengan skala VAS

Untuk mengukur dan mengetahui derajat nyeri pasien dengan menggunakan skala VAS (Visual Analogue Scale). VAS adalah pengukuran derajat nyeri dengan menunjukan 


\section{Indonesian Journal of Health Science}

Volume 1 No. 1, Juni 2021

satu titik pada garis skala nyeri 0-10, dimana 0 menunjukan tidak adanya nyeri sama sekali, 5 terdapat nyeri yang mengganggu aktifitas, sedangkan 10 menunjukan adanya nyeri tak tertahankan dan menyebabkan pasien tidak dapat melakukan aktifitasnya sama sekali. Terdapat tiga pemeriksaan nyeri yaitu nyeri diam, nyeri tekan, dan nyeri gerak.

b. Pengukuran antropometri menggunakan mide line untuk mengukur oedem

c. Pengukuran LGS dengan goniometer

Pemeriksaan lingkup gerak sendi (LGS) dilakukan untuk mengetahui keterbatasan ROM yang terjadi pada regio bahu dengan menggunakan goniometer.

d. Pemeriksaan kekuatan otot dengan Manual Muscle Testing (MMT)

Pemeriksaan ini dilakukan untuk menilai kekuatan otot pasien.

e. Rontgen area bahu

\section{Intervensi Fisioterapi Pra Operasi}

Intervensi yang dapat diberikan oleh seorang fisioterapis pada kasus dislokasi sendi bahu adalah dengan pemberian PRICE (protection, rest, ice, compression, elevation).

\section{Protection}

Pemberian proteksi yang dilakukan untuk mencegah terjadinya cidera tambahan.

2. Rest

Mengistirahatkan area bahu yang dilakukan agar tidak terjadi stress pada area yang cidera yang dapat menghambat proses penyembuhan. Namun, dibeberapa kasus gerakan isometrik dapat membantu proses penyembuhan sehingga tetap lakukan latihan gerak pada regio post cidera.

3. Ice

Pemberian ice atau cryotherapy dapat membantu mengurangi pembengkakan dan nyeri. Aplikasikan es selama 10-15 menit setiap 2 jam.

4. Compression

Pemberian tekanan pada area cidera untuk membantu mengurangi pembengkakan dengan mengaplikasikan elastic bandage. Bandage dipasang beberapa centi diatas dan dibawah area cidera. Bandage tidak boleh menyebabkan pasien mengalami mati rasa, kesemutan, ataupun perubahan warna jaringan lunak untuk mengurangi resiko kematian jaringan.

5. Elevation

Elevasi dianjurkan untuk membantu mengurangi penumpukan cairan di ekstremitas atau sendi yang cidera. Mengontrol pembengkakan dapat membantu mengurangi rasa sakit dan dapat membatasi hilangnya lingkup geras sendi, sehingga dapat mempercepat waktu pemulihan.

Setelah pemberian PRICE pasien dengan dislokasi harus segera dirujuk ke rumah sakit

\section{Intervensi Fisioterapi Post-Operasi}

Dislokasi sendi biasanya jarang berakibat fatal hingga menyebabkan kematian, tetapi dapat menyebabkan penderitaan fisik, stress mental, dan kehilangan banyak waktu. Oleh karena itu, pada kasus dislokasi sendi akan meningkatkan angka morbiditas dibanding angka mortalitas (Salter R, 1999). Sebelum melakukan intervensi fisioterapis harus menentukan diagnosis fisioterapi terlebih dahulu. Diagnosis fisioterapi pada pasien dengan kasus dislokasi sendi bahu yaitu: 


\section{Indonesian Journal of Health Science}

Volume 1 No. 1, Juni 2021

\section{Impairment}

Permasalahan yang di dapat berhubungan dengan impairment meliputi: adanya nyeri tekan dan gerak pada bahu kanan, terdapat spasme pada M. Biceps bracialis, terdapat penurunan LGS pada bahu, terdapat penurunan kekuatan otot pada bahu.

\section{Fungsional Limitation}

Permasalahan yang terjadi berhubungan dengan adanya penurunan aktivitas fungsional pasien yaitu adanya gaangguan Ketika pasien mengambil barang yang berada di atas, dan gerakan-gerakan yang melibatkan, fleksi, ekstensi, abduksi, dan adduksi.

\section{Disability}

Pasien masih dapat mengikuti kegiatan di lingkungan sekitarnya. Hanya tidak semaksimal seperti sebelum sakit.

Maka dari itu, tujuan dari intervensi yang akan diberikan adalah untuk mengurangi nyeri tekan, meningkatkan LGS bahu, menurunkan spasme M. Biceps bracialis, meningkatkan kekuatan otot, dan mengembalikan aktivitas fungsional pasien. Untuk mengatasi permasalahan tersebut fisioterapis memberikan intervensi modalitas infrared dan terapi latihan.

1. Infrared

Infrared irradiation (IRR)merupakan energi elektromagnetik yang tidak terlihat oleh mata manusia, memiliki panjang gelombang antara $760 \mathrm{~nm}-1 \mathrm{~mm}$. Dalam spektrum elektromagnetik, inframerah memiliki tempat antara cahaya tampak (visible light) dan gelombang mikro (microwaves).

Adapun efek yang diberikan dari infrared adalah efek fisiologis dan terapeutik. Efek fisiologis meliputi peningkatan metabolisme, pelebaran pembuluh darah, pigmentasi, efek rileksasi pada saraf sensorik, efek mengurangi spasme jaringan otot, dan aktivasi kelenjar keringat. Efek terapeutik yang dihasilkan adalah pereda nyeri, relaksasi otot, dan peningkatan suplai darah (Sujatno, 2002). Berdasarkan hal tersebut infrared dapat bermanfaat pada kasus dislokasi sendi bahu.

\section{Terapi Latihan}

Terapi latihan adalah terapi yang diberikan kepada pasien atau klien dalam bentuk suatu program latihan yang disusun secara sistematis dan terencana dari pergerakan fisik, postur, atau aktivitas fisik tertentu. Tujuan dari terapi ini adalah untuk mencegah terjadinya impairment, meningkatkan, mengembalikan dan mengoptimalkan fungsi fisik, mencegah dan mengurangi faktor risiko, optimalisasi status kesehatan secara umum, fitness dan kualitas hidup (Kisner, 2017).

Latihan untuk kasus dislokasi acromionclavicular joint adalah dengan menggunakan Shoulder Wheel. Shoulder Wheel adalah perangkat berbentuk roda yang dipasang ke dinding pada poros roda yang setinggi bahu. Pegangan terletak di sudut kanan pada salah satu palang roda. Shoulder Wheel memiliki baut atau sekrup yang digunakan untuk menyesuaikan ukuran soket pada alat. Roda digunakan untuk meningkatkan LGS secara aktif dengan gerakan kompleks. Hambatan yang tercipta saat latihan dengan Shoulder Wheel dicapai dengan mengencangkan atau mengendurkan baut pada poros palang. Pada posisi awal, roda pada bahu dapat berputar bebas tanpa gaya. Tahanan dan dapat ditingkatkan dengan memutar pin pemasangan poros ke kanan. Selain resistensi, barbel juga dapat digunakan untuk memperkuat otot-otot di sekitar bahu (Samudro, 2013).

Terapi Latihan yang digunakan dalam penelitian ini adalah dengan teknik static contraction, free active movement, assisted active movement dan passive movement yang 


\section{Indonesian Journal of Health Science}

Volume 1 No. 1, Juni 2021

digunakan berfungsi untuk mengurangi nyeri sehingga kekuatan otot dapat meningkat serta menambah LGS sehingga terjadi perbaikan pola gerak (Samudro, 2013).

\section{Static contraction}

Adalah latihan dengan mengontraksikan otot tanpa gerakan. Tujuan dari latihan ini adalah untuk mengurangi bengkak dan nyeri.

2. Free active movement

Adalah latihan dengan menggerakan segmental sendi yang berasal dari kontraksi otot secara aktif tanpa adanya bantuan dari luar. Gerakan tersebut akan menimbulkan relaksasi pada otot sehingga dapat menurunkan nyeri.

3. Assisted active movement

Adalah gerakan segmental sendi yang dilakukan secara aktif dibantu dengan gaya dari luar untuk menyelesaikan gerakan.

\section{Passive movement}

Adalah gerakan segmental sendi yang dihasilkan berasal dari gaya dari luar (gravitasi, mesin, fisioterapis dan bagian tubuh individu yang sehat).

Setelah pemberian intervensi tersebut fisioterapis memberikan edukasi kepada pasien untuk latihan di rumah seperti yang dianjurkan trapis, pasien sementara tidak di perbolehkan mengangkat benda yang berat, pasien disarankan jangan melakukan gerakan yang menyebabkan hyperstress.

\section{PENUTUP}

\section{Simpulan}

Sendi bahu adalah sendi yang paling umum terjadi dislokasi, dikarenakan rentang gerak pada sendi glenohumeral yang luas, dangkalnya fossa glenoid, dan juga ligament laxity pada beberapa orang (Samudro, 2013). Apabila sendi sudah pernah mengalami dislokasi, maka biasanya ligamen-ligamen pada sendi tersebut sudah menjadi longgar sehingga meningkatkan resiko terjadinya dislokasi kembali. Dislokasi biasanya terjadi akibat benturan yang tiba-tiba yaitu yang disebabkan kerena seseorang terjatuh, terpukul benda keras, atau cedera lainnya. Ketika seseorang terjatuh tulang humerus akan terdorong ke depan, sehingga merobek kapsul atau menyebabkan tepi glenoid teravulasi, dan terkadang menyebabkan pecahnya bagian posterolateral caput humerus (Setiyawan, 2013). Hal tersebut akan menimbulkan adanya nyeri, deformitas, keterbatasan gerak, penurunan kekuatan otot, dan penurunan aktivitas fungsional pada pasien dengan dislokasi sendi bahu. Hasil penelitian menunjukkan bahwa pemberian terapi latihan dan terapi infrared efektif untuk menurunkan nyeri, meningkatkan kekuatan otot, meningkatkan lingkup gerak sendi (LGS), serta meningkatkan kemampuan fungsional pasien yang menderita kasus dislokasi sendi.

\section{Saran}

Pasien dengan dislokasi sendi hendaknya melakukan terapi dengan rutin, dan menjalankan homeprogram yang diberikan oleh fisioterapis dengan bersungguh-sungguh untuk proses penyembuhan yang lebih cepat. Hendaknya penelitian selanjutnya lebih mendalami mekanisme yang terjadi dengan diberikannya intervensi infrared dan terapi latihan. Bagi masyarakat umum hendaknya selalu berhati-hati ketika melakukan suatu aktivitas tertentu yang dapat meningkatkan risiko terjadinya dislokasi bahu.

\section{DAFTAR PUSTAKA}

Adams, J. C. (1972). Outline of Orthopaedic; Fifth Edition. Edinburgh and London: E. S. Livingstone Ltd. 


\section{Indonesian Journal of Health Science}

Volume 1 No. 1, Juni 2021

Apley, A. G. (2010). Ortopedi dan Fraktur sistem Apley, Ninth edition ISE. Jakarta: CRC Press.

Bakhsh, W. \&. (2018). Anatomy and Physical Examination of the Shoulder. Review Article, 10.

Celcilia, E. (2015). Gambaran Skor Trauma Pada Pasien Di UGD RSUD DR SOEDARSO Pontianak Memnggunakan Revised Trauma Score (RTS) Periode Tahun 2012 . Naskah Publikasi, 3.

DocDoc Pte Ltd. (2020). Apa itu Trauma? Retrieved from Docdoc: https://www.docdoc.com/id/info/condition/cedera

Dogrul, B. N. (2020). Blunt trauma related chest wall and pulmonary injuries: An overview. Chinese Journal of Traumatology, 125.

F, K. d. (2015). Management of recent first-time anterior shoulder dislocations . Orthopaedics \& Traumatology: Surgery \& Research.

Kasyfi, L. N. (2020). Dislokasi Sendi Bahu: Epidemiologi Klinis dan Tinjauan Anatomi. Sriwijaya University Repository, 3.

Kisner, C. (2017). Therapeutic exercise : foundations and techniques. Philadelphia: F. A. Davis Company.

Koval, K. J. (2006). Upper Extremity Fractures and Dislocations. Handbook of Fractures, 148164.

Legiran, N. R. (2015). Dislokasi Sendi Bahu: Epidemiologi Klinis dan Tinjauan Anatomi. Sriwijaya University Institutional Repository, 3.

Neumann, D. A. (2017). Kinesiology of the Musculoskeletal System: Foundations for Rehabilitation Third Edition. Canada: Elsevier, Inc.

Nugraha, A. R. (2020). Purwarupa Aplikasi Terapi Dislokasi Lengan Untuk Rehabilitasi Pasca Cedera Berbasis Leap Motion. Elibrary UNIKOM, 2.

Ozan. (2019, November 8). Pro Ball Mastery By Anfa. Retrieved from Mengetahui Klasifikasi Cedera dalam Olahraga: http://proballmastery.com/2019/11/08/mengetahui-klasifikasicedera-dalam-olahraga/

Priyonoadi, A. S. (2012). Terapi Masase Frirage Penatalaksanaan Cedera Pada Anggota Gerak Tubuh Bagian Bawah. Yogyakarta: Digibooks.

Salter R, B. (1999). Textbook of Disorder and Injuries of the Musculoskeletal System, 3rd-ed. Baltimore: Williams \& Wilkins.

Samudro, H. B. (2013). Penatalaksanaan Fisioterapi Dengan Terapi Latihan Dan Infra Red (IR) Pada Kondisi Post Dislokasi Sendi Acromioclavicular Dextra. Naskah Publikasi Tugas Akhir, 4.

Setiyawan, A. (2013). Penatalaksanaan Fisioterapi Pada Post Dislokasi Shoulder Dextra Di RSUD Sukoharjo. Naskah Publikasi Tugas Akhir, 2.

Sujatno, K. H. (2002). Sumber Fisis. Poltekkes Surakarta Jurusan Fisioterapi.

Zachilli, M. A. (2010). Epidemiology of Shoulder Dislocations Presenting to Emergency Departments in the United States. The Journal Of Bone and Joint Surgery, 542-549. Retrieved from Bone Joint Surgery. 